\title{
Evaluation of in vivo mutagenesis for assessing the health risk of air pollutants
}

Yasunobu Aoki

\begin{abstract}
Various kind of chemical substances, including man-made chemical products and unintended products, are emitted to ambient air. Some of these substances have been shown to be mutagenic and therefore to act as a carcinogen in humans. National pollutant inventories (e.g., Pollutant Release and Transfer Registration in Japan) have estimated release amounts of man-made chemical products, but a major concern is the release of suspended particulate matter containing potent mutagens, for example, polycyclic aromatic hydrocarbons and related compounds generated by the combustion of fossil fuel, which are not estimated by PRTR system. In situ exposure studies have revealed that DNA adducts in the lung, and possibly mutations in germline cells are induced in rodents by inhalation of ambient air, indicating that evaluating in vivo mutations is important for assessing environmental health risks. Transgenic rodent systems (Muta, Big Blue, and gpt delta) are good tools for analyzing in vivo mutations induced by a mixture of chemical substances present in the environment. Following inhalation of diesel exhaust (used as a model mixture), mutation frequency was increased in the lung of gpt delta mice and base substitutions were induced at specific guanine residues (mutation hotspots) on the target transgenes. Mutation hotspots induced by diesel exhaust were different from those induced by benzo[a]pyrene, a typical mutagen in ambient air, but nearly identical to those induced by 1,6-dinitropyrene contained in diesel exhaust. Comparison between mutation hotspots in the TP53 (p53) gene in human lung cancer (data extracted from the IARC TP53 database) and mutations we identified in gpt delta mice showed that $G$ to $A$ transitions centered in CGT and CGG trinucleotides were mutation hotspots on both TP53 genes in human lung cancers and gpt genes in transgenic mice that inhaled diesel exhaust. The carcinogenic potency $\left(\mathrm{TD}_{50}\right.$ value) of genotoxic carcinogen was shown to be correlated with the in vivo mutagenicity (total dose per increased mutant frequency). These results suggest that the mutations identified in transgenic rodents can help identify environmental mutagens that cause cancer.
\end{abstract}

Keywords: Air pollutant, Environmental mutagen, Genotoxic carcinogen, In situ exposure, Lung, Mutation hotspot, Polycyclic aromatic hydrocarbon, Risk assessment, Transgenic rodent gene mutation assay

\section{Background}

Various chemical substances, including man-made products and unintended products, have been and continue to be emitted into the environment, such as ambient air, water, and soil; of these environmental media, ambient air is the major destination of pollutants. The Japanese national inventory for the release of chemicals to the environment (Pollutant Release and Transfer Registration, PRTR) [1] contains statistics of releases notified by businesses (point sources) and the releases outside

\section{Correspondence: ybaoki@nies.go.jp}

National Institute for Environmental Studies, Center for Health and Environmental Risk Research, 16-2 Onogawa, Tsukuba, Ibaraki 305-8506, Japan

(c) The Author(s). 2017 Open Access This article is distributed under the terms of the Creative Commons Attribution 4.0 International License (http://creativecommons.org/licenses/by/4.0/), which permits unrestricted use, distribution, and reproduction in any medium, provided you give appropriate credit to the original author(s) and the source, provide a link to the Creative Commons license, and indicate if changes were made. The Creative Commons Public Domain Dedication waiver (http://creativecommons.org/publicdomain/zero/1.0/) applies to the data made available in this article, unless otherwise stated. 
[2]. These data indicate that measurable amounts of carcinogens are released to ambient air, although the annual average concentrations of these substances in ambient air were not over the environmental quality standard $\left(3 \mu \mathrm{g} / \mathrm{m}^{3}\right.$ for benzene) and the guideline value $(2.5 \mu \mathrm{g} /$ $\mathrm{m}^{3}$ for 1,3-BD) at any monitoring stations in urban areas in Japan in fiscal year 2013 [3].

While the release of man-made chemicals has been comprehensively estimated in industrial countries by governments and non-governmental organizations, registration of the amount of unintended products released to the environment is limited; for example, dioxins are the only unintentionally-produced by-product whose release has been registered in PRTR in Japan [2]. However, it is wellknown that various kinds of unintentionally-produced byproducts are generated by the combustion of fossil fuel, for example, in automobile engines (such as diesel engines) and in heating processes, and are emitted mainly to ambient air as components of suspended particulate matter (SPM). Some unintended products in ambient air are suspected to cause lung cancer and other respiratory disease, such as asthma [4-6].

The soot generated by combustion of coal was the earliest-discovered air-born carcinogen; in the $18^{\text {th }}$ century, it was discovered that heavy exposure to soot causes skin tumors in humans, and in the early $20^{\text {th }}$ century, benzo[a]pyrene $(\mathrm{BaP})$, a polycyclic aromatic hydrocarbon (PAH) contained in soot, was identified as a carcinogen (for review, see [7]). In recent decades, some PAHs, including nitrated PAHs, contained in SPM have been shown to be genotoxic and have been categorized as IARC Group 1 (e.g., BaP) or IARC Group 2A/2B (suspected human carcinogens) [8]. For instance, the exhaust of diesel engines is classified as IARC Group 1 [9]. These facts indicate that mixtures of mutagenic and/or carcinogenic combustion products have been released into the air and inhaled by habitats in urban areas.

Epidemiological studies in the United States [10,11] and Japan [12] show an association between the incidence of disease (lung cancer and respiratory disease) and long-term exposure to air pollution including SPM with a diameter below $2.5 \mu \mathrm{m}$ (PM2.5). Recent investigations conclude that outdoor air pollution is classified as IARC Group 1 [13]. However, the cancer risk of air pollutant mixtures that contain mutagenic by-products of combustion has only been evaluated on the basis of limited epidemiological data. To improve the health risk assessment of whole air pollutants, it is necessary to conduct experimental animal studies to quantitatively evaluate how the exposure to a mixture of air pollutants induces DNA damage, such as DNA adducts, that can lead to in vivo mutagenesis and potentially carcinogenesis; furthermore, it is important to know whether such air pollutants could induce mutations in germline cells.

\section{Induction of DNA damage by inhalation of mutagens}

The presence of mutagens in ambient air, especially in SPM, has been surveyed in various countries by using in vitro bioassay systems, such as the Ames test [14, 15]. Studies in Japan have shown that mutagens are ubiquitously present in air-borne particles collected in large cities [16]. Matsumoto et al. [17] reported that the contents of the PM2.5 fraction collected at an intersection with heavy traffic in Tokyo exerted higher mutagenicity than did larger air-borne particles from the same location. Watanabe et al. [18] showed that the soil in the Kyoto area contained mutagenic compounds that might be deposits from air, and identified the major mutagens as nitrated PAHs such as 3,6-dinitrobenzo[e]pyrene. The identification of various mutagens in ambient air indicates that people inhale a mixture of various mutagens, rather than a single mutagen.

Inhalation of a mixture of mutagens has been suspected to induce DNA damage resulting in carcinogenesis in target organs and, in some cases, mutagenesis in the germ cells. Although DNA adduct formation, micronucleus induction, and DNA strand breaks in surrogate tissues, for example white blood cells, have been analyzed as biomarkers for assessing the genotoxicity of tobacco smoke $[19,20]$, the total mutagenicity of the environmental mixture in ambient air remains to be clarified. Formation of DNA adducts has been shown to be elevated in the white blood cells of individuals heavily exposed to air pollutants [21]; however, the amount of DNA adducts induced in target tissues, especially lung, by air-borne chemicals needs to be analyzed to assess the mutagenicity of the whole environmental mixture. Since analysis of DNA adducts in lung tissue cannot be conducted for human populations, studying the exposure of experimental animals, such as rodents, to ambient air (in situ exposure), is a limited but potentially effective method for addressing the issue of how a whole mixture of air pollutants is mutagenic [22].

\section{In situ exposure of experimental animals to ambient air}

We conducted an in situ exposure study for a 60-week period from 1996 to 1997 in which rats were maintained in polluted air containing SPM with a diameter of $<11 \mu \mathrm{m}$ at an average monthly concentration of $76.5 \mu \mathrm{g} /$ $\mathrm{m}^{3}$ (range $50.4-108.3 \mu \mathrm{g} / \mathrm{m}^{3}$ ). The rats were housed in a small animal facility located beside an intersection with heavy traffic in the Tokyo metropolitan area, and air was circulated from the outside environment [23]. DNA adduct analysis revealed that the levels of DNA adducts, some of which were probably PAH-DNA adducts, were elevated in lungs, nasal mucosa, and livers of rats after exposure to urban air for 4 weeks, with the levels decreasing gradually during prolonged exposure over 12 weeks; these results indicate that urban air exerts genotoxic effects not only directly in respiratory organs, 
such as lung and nasal mucosa, but also indirectly in tissues remote from respiratory organs, such as liver. An in situ exposure study in São Paulo showed induction of micronuclei in peripheral erythrocytes of mice following exposure to urban air for 90 days [24]. In an earlier in situ exposure study, coke oven emissions containing $892 \mathrm{ng} / \mathrm{m}^{3}$ PAHs, as a model mixture of air pollution, were shown to induce DNA adduct formation in the lungs and non-respiratory tissues (heart, liver, and white blood cells) of rats [25]. These results suggest that air pollution in urban areas causes somatic mutations.

Analysis of mutagenesis not only in somatic cells but also in germ cells has been a major issue in environmental mutagen research. In situ exposure to ambient air in a polluted area near a steel mill in Canada in 1999 showed that the frequency of inheritable mutations at expanded simple tandem repeat (ESTR) loci was significantly higher in mice exposed to polluted ambient air for 10 weeks compared to those in a non-polluted area [26]; ESTR mutations are detected as a change in the number of tandem repeats in the ESTR loci (e.g., Ms6$\mathrm{hm}$ ). Interestingly, the elevation of heritable mutations at the ESTR loci was originally observed in a herring gull (Larus argentatus) population nesting in a polluted area near steel mills $[27,28]$. Somer et al. [29, 30] and Yauk et al. [31] demonstrated that the frequency of ESTR mutations in mice exposed to polluted air near steel mills and a highway was 1.6 times higher than that of mice exposed to air that was SPM depleted by high-efficiency particulate arrestance (HEPA)-filtration at the same location, indicating that SPM can potentially increase the mutation frequency at ESTR loci. DNA strand breaks in sperm and DNA-adduct formation in lung were also found to be elevated in mice exposed to polluted air containing total SPM (mean $93.8 \pm 17.0 \mu \mathrm{g} / \mathrm{m}^{3}$ ) or PAHs (mean $8.3 \pm 1.7 \mathrm{ng} / \mathrm{m}^{3}$ ), for 3 or 10 weeks, respectively [31]. These increases in heritable mutations at ESTR loci suggest that exposure to air-borne particulates containing mutagens can cause germ cell mutations. An elevated frequency of mutations at ESTR loci was also observed in mouse sperm following exposure of the mice to tobacco smoke (mainstream tobacco smoke [32] or sidestream tobacco smoke [33]). Irradiation studies showed that the average doubling dose of ESTR mutations following low linear energy transfer (LET) irradiation of spermatogonia or stem cells was $0.62-0.69$ Gy [34]. However, the mechanism for inducing ESTR mutations is still unknown, and further studies are required to resolve the biological significance of ESTR mutations [34].

\section{Transgenic rodents as a tool for analyzing in vivo mutagenesis by air pollutants}

The observations in the above in situ exposure studies raise the question of whether DNA damage induced by exposure to air pollutants becomes fixed as in vivo mutations in the target tissues. To answer this question, transgenic rodents (Muta, Big Blue, and gpt delta) are useful, because they allow analysis of in vivo mutations induced by environmental mutagens.

In the Muta, Big Blue, and gpt delta systems, a target gene for detecting mutations (lacZ encoding E. coli $\beta$ galactosidase, lacI encoding the $E$. coli lactose operon repressor, or gpt encoding E. coli guanine phosphoribosyltransferase, respectively) carried on a $\lambda$ phage shuttle vector is integrated into the genomic DNA (for review, see [35]). Transgenic mice, harboring genome-integrated DNA plasmids containing the lacZ gene were also established [36, 37]. After Muta, Big Blue, and gpt delta rodents are exposed to mutagen, the shuttle vector is rescued from the genomic DNA to host $E$. coli, and (1) the mutated target gene is detected by phenotypic transformation of the host $E$. coli, that is the appearance of $\beta$ galactosidase-null plaques, $\beta$-galactosidase-expressing plaques, and 6-thioguanine-resistant colonies, respectively, (2) the $c I I$ gene on the $\lambda$ phage shuttle vector can also be used as the target gene (for review, see [35]), and (3) the gpt delta system can be applied to detect large deletions on genomic DNA.

Transgenic rodents have been used for the analysis of in vivo mutagenicity of carcinogenic air-borne chemicals such as 1,3-BD, ethylene oxide, and PAHs. For example, inhalation of 1,3-BD at a concentration of $625 \mathrm{ppm}$ by Muta mice for 5 days accelerated in vivo mutagenesis in lung but not in bone marrow or liver [38]. When Big Blue mice were exposed to $1,3-\mathrm{BD}$ at the same concentration and for the same time period as that used for Muta mice above, the results demonstrated that 1,3-BD is mutagenic in bone marrow [39]. Recio et al. [39] proposed that the difference in in vivo mutagenicity of 1,3$\mathrm{BD}$ in bone marrow between Muta mice and Big Blue mice might be due to differences in 1,3-BD bioactivation between the host strains (CD2F1 and B6C3F1, respectively). Following 2-year inhalation exposure to $1,3-\mathrm{BD}$, an increased incidence of neoplasms in the hematopoietic system was shown in B6C3F1 [40]. Furthermore, when Big Blue mice were exposed to 1,3-BD at a concentration of $1250 \mathrm{ppm}$ for 4 weeks, the frequency of mutations at A:T pairs was significantly increased in bone marrow [41], and the frequency of $\mathrm{G}$ to $\mathrm{A}$ transitions was significantly increased at non-CpG sites in spleen [42, 43]. Formation of persistent DNA adducts derived from 1,3-BD on adenine residues [44] may contribute to the increased frequency of mutation at A:T pairs. Elevation of in vivo mutagenesis in lung by ethylene oxide was also demonstrated by an inhalation study using Big Blue mice $[45,46]$. The relative potencies of in vivo mutagenicity were compared among PAHs administered by intraperitoneal (ip) injection to Big Blue mice [47] or orally to Muta mice [48]. 
The results indicated that in vivo mutagenicity in lung was as high for dibenzo $[a, l]$ pyrene as for BaP; however, whereas $\mathrm{G}$ to $\mathrm{T}$ transversions and $\mathrm{G}$ to $\mathrm{A}$ transitions were the major base substitutions induced in lung by dibenzo[a,l]pyrene, $\mathrm{G}$ to $\mathrm{T}$ transversions were the sole major base substitution induced in lung by $\mathrm{BaP}$ [47]. Our group's intratracheal administration studies showed that the mutant frequency in vivo of 1,6-DNP [49] was about 20 times higher than that of $\mathrm{BaP}$ [50]. These observations indicate that transgenic rodent assay systems are a useful tool for analyzing in vivo mutations induced in lung and other respiratory organs by environmental chemicals inhaled from ambient air.

\section{Analysis of in vivo mutagenesis induced by diesel exhaust as a model mixture of air pollutants}

By using various transgenic rodents, our group examined the in vivo mutagenicity of diesel exhaust emitted from an engine. Diesel exhaust is an appropriate model of air pollution in urban areas, because it is the major source of genotoxic carcinogens, such as PAHs, as mentioned above. We showed that inhalation of diesel exhaust, at an SPM concentration of $6 \mathrm{mg} / \mathrm{m}^{3}$ for 28 days, by Big Blue rats increased the mutant frequency, and elevated the level of DNA adducts, in lung [51]. In contrast, feeding of standard reference material of diesel particles at a concentration $80 \mathrm{mg} / \mathrm{kg}$ body weight for 21 days increased the level of DNA damage in colon and liver [52] and lung [53] of Big Blue rat, but did not elevate in vivo mutagenicity in these organs.

Our inhalation study using gpt delta mice also demonstrated that the frequency of in vivo mutation increased in lung depending on the duration of exposure to diesel exhaust at an SPM concentration of $3 \mathrm{mg} / \mathrm{m}^{3}$ [54]. The mutant frequency was elevated to $2.11 \pm 0.08 \times 10^{-5}$ in exposed mice compared with $0.82 \pm 0.07 \times 10^{-5}$ in control mice, after 24-weeks exposure. However, inhalation of standard reference material of diesel particles for $90 \mathrm{~min}$ at a concentration of $80 \mathrm{mg} / \mathrm{m}^{3}$ on a single day or 4 consecutive days did not elevate the in vivo mutagenicity in the lungs of Muta mice [55]. Our studies using transgenic rodents demonstrate that diesel exhaust emitted from an engine induces in vivo mutagenesis in lung, whereas induction of micronuclei in reticulocytes was not observed in mice and rats by exposure of diesel exhaust at the low concentration (about $30 \mu \mathrm{g} / \mathrm{m}^{3}$ ) for 3 months $[56,57]$.

Sequence analysis of mutated gpt genes rescued from the diesel exhaust-exposed lungs of gpt delta mice revealed that the most frequent type of base substitution on gpt gene induced by exposure to diesel exhaust was $\mathrm{G}$ to A transitions [58], and the next most common was the $\mathrm{G}$ to $\mathrm{T}$ transversions. Mutation hotspots (mutation loci identified from three or more mice) were present at nucleotide numbers 64,110 , and 115 for $G$ to $A$ transitions and $185,401,402,406$, and 418 for G to A transitions and $\mathrm{G}$ to $\mathrm{T}$ transversions; this is recognized as a molecular signature for mutation induced by oxidative stress [59] or exposure to $\mathrm{BaP}$ in lung [50]. Since nucleotide numbers 64 and 110 were sites of mutation in non-exposed mice, the components in diesel exhaust possibly enhanced the frequency of spontaneouslyinduced mutations, but mutations at nucleotide numbers $185,401,402,406$, and 418 may be a unique signature for exposure to diesel exhaust. Interestingly, these hotspots induced by diesel exhaust were different from those induced by intratracheally-administered $\mathrm{BaP}$, that is $\mathrm{G}$ to $\mathrm{T}$ transversions at nucleotide numbers 125,140 , 143 , and 413 [50], but similar to those induced by intratracheally administered 1,6-DNP [49], suggesting that components other than $\mathrm{BaP}$ in diesel exhaust were the major inducers of in vivo mutagenesis in lung. Hotspots of mutation in the livers of phenacetin-dosed gpt delta rats, that is nucleotide numbers 26 and 416 [56], are different from those induced by exposure to diesel, 1,6$\mathrm{DNP}$, or BaP. Therefore, hotspots of mutation in target genes integrated into the genomic DNA of rodents are potentially specific landmarks for identifying a type of exposed mutagen.

\section{Germline mutations induced by mutagens contained in diesel exhaust}

Following inhalation of diesel exhaust to gpt delta mice, we observed an increase in the mutant frequency in testis, but not in liver, suggesting that diesel exhaust or mutagens in diesel exhaust might induce mutations in male germline cells such as sperm [58]. However, this observation contrasted with in vivo mutagenicity of a heterocyclic amine, 2-Amino-1-methyl-6-phenylimidazo[4,5-b]pyridine (commonly known as PhIP), which induced mutations in liver but not in testis [60]. Any mutagens in diesel exhaust may be specifically distributed to the testis and induce mutations in this organ. Abnormal morphology of sperm is reported to be correlated to the level of air pollution in the human population of the Czech Republic [61], but it is yet to be revealed whether air pollution causes germline mutations.

Transgenic rodents are also a good model for evaluating induction of germline mutations. Administration of a potent mutagenic alkylating agent, ethylnitrosourea or isopropyl methanesulfonate, to Muta mice by a single ip injection induced mutations in the lac $Z$ target gene, and genomic DNA rescued from seminiferous tubule germ cells after a period of mutation expression for 52 days, showed a significant increase in the mutant frequency in germline cells [62]. When inherited germline mutations induced by ethylnitrosourea were examined using gpt delta mice, the frequency of inherited mutations in the offspring of ethylnitrosourea-treated mice was 17-fold 
higher than that of the offspring of control mice [63]. A longer expression period was required to detect mutations in germline cells than somatic cells, because it takes a prolonged period to fix mutagen-induced DNA lesions in stem cells of germline as a mutation in differentiated germline cells [64].

Regarding environmental mutagens, germ cell mutations induced by $\mathrm{BaP}$ have also been examined in transgenic rodents. After transgenic mice bearing pUR288 lac $Z$ were administered $\mathrm{BaP}$ by gavage at a dose of $13 \mathrm{mg} / \mathrm{kg}$ body weight 3 times per week for 6 weeks, DNA adducts were induced in testis; however, the mutant frequency increased in sperm but not in testis [65]. In contrast, an increased mutant frequency in sperm was not observed in mice homozygous deficient for the $X p c$ gene, which plays a role in the removal of bulkyDNA adducts [65]. Formation of BaP-DNA adducts in stem cell spermatogonia was shown to give rise to de novo mutations in the sperm $[66,67]$, and exposure to $\mathrm{BaP}$ in earlier life (5-days-old) induced elevated mutant frequency in spermatogenic cells more effectively than exposure to $\mathrm{BaP}$ in the adult stage [68]. A singlemolecule PCR method was established to measure induction of mutations at ESTR loci [69]. Using this method, administration of $\mathrm{BaP}$ by gavage at a dose of $100 \mathrm{mg} / \mathrm{kg}$ body weight for 28 days was shown to induce ESTR mutations in the sperm of Muta mice [70].

Male germline mutations at ESTR loci were also enhanced in the offspring of female mice who inhaled standard reference material of diesel particles [71] or were subjected to irradiation by X-ray [72]. These observations suggest that $\mathrm{BaP}$ and other mutagens in diesel exhaust could be germ cell mutagens. An interesting comparative study has reported that one adduct formation of BaP has approximately the same mutagenicity as $10^{-4}$ Gy r-irradiation [73]. Further studies, similar to those for ethylnitrosourea [74], are required to quantitatively evaluate germ cell mutagenesis induced by low-dose subchronic exposure to $\mathrm{BaP}$.

\section{Mutation on Ras proto-oncogenes and TP53 (tumor suppressor gene) in somatic cells by environmental mutagens}

Induction of somatic mutation(s) at specific sequences on proto-oncogenes and/or tumor suppressor genes is a key process in carcinogenesis. To reveal how mutation at these specific sequences is induced by environmental mutagens is an important issue for understanding the mechanism of mutagenesis and carcinogenesis induced by environment mutagens. Furthermore, mutations on the unique sequences are candidate molecular signatures for monitoring the exposure of mutagens.

Observations of mutations at codons 12,14 , or 61 , of Ras genes in human cancer have been well-documented
[75]. In chemical carcinogenesis studies, the Hras gene was mutated at codon 61 in mouse hepatomas induced by exposure to $N$-hydroxy-2-acetylaminofluorene, vinyl carbamate, or $1^{\prime}$-hydroxy-2', $3^{\prime}$-dehydroestragole [76], and analysis of DNA adduct formation revealed the binding of benzo[a]pyrene diol epoxide (BPDE, reactive intermediate of $\mathrm{BaP}$ ) to guanine or adenine in codons 12 and 14 or of Kras gene in cultures of normal human bronchial epithelial cells treated with BPDE [77].

In vivo mutagenesis of the Kras gene has been analyzed by allele-specific competitive blocker PCR (ACB-PCR). After Big Blue rats were treated with $N$-hydroxy-2-acetylaminofluorene, the frequencies of GGT to GTT and GGT to GAT substitutions at Kras codon 12 in liver were 3.3 and 6.4 times, respectively, those in the control, while transgenic rodent assay showed that $G$ to $\mathrm{T}$ transversion was the major base substitution induced by $N$-hydroxy-2-acetylaminofluorene [78]. In contrast, treatment of Big Blue rats with aristolochic acid significantly increased the frequency of GAA to GTA substitutions at Kras codon 61 in liver and kidney, but did not induce GGT to GAT substitution at Kras codon 12 [79]. The frequencies of GGT to GTT and GGT to GAT substitution at Kras codon 12 were elevated by inhalation of ethylene oxide at $100 \mathrm{ppm}$ and 50-200 ppm, respectively, for 4 weeks, but this effect was not observed following inhalation for 8 weeks [80]; the authors speculated that negative selection against cells carrying Kras mutations occurred at the high cumulative dose of ethylene oxide. The results suggest that environmental mutagens induce mutations site-specifically on the Kras gene.

Mutations in the TP53 (p53) tumor suppressor gene are frequently observed in human cancer [81, 82]. The IARC TP53 database [83] compiles data on TP53 mutations detected in human cancer, and provides useful information for understanding the mechanism of carcinogenesis. Analysis of this database reveals that the TP53 gene is mutated frequently at several specific codons in cancer. For example, in BPDE-treated HeLa cells and bronchial epithelial cells, BPDE-DNA adducts frequently form at commonly mutated codons in the TP53 gene (codons 157, 248, and 273) [84], suggesting that a unique mutation spectrum was induced by each mutagen on the TP53 gene. To compare the TP53 mutation spectra produced by various environmental mutagens, human p53 knock-in (Hupki) mouse lines were established and an in vitro assay for detecting mutations induced on the human TP53 gene was developed [85]. In the Hupki mouse genome, the DNA-binding domain of the mouse Trp53 (Tp53) gene has been replaced with the normal human TP53 gene by using gene-targeting technology. For the in vitro assay, cultures of Hupki mouse-derived embryonic fibroblast (HUF) cells were treated with chemical substances; immortalized cells 
were obtained following several passages of treated cells; and the humanTP53 gene in the immortalized cells was subjected to sequencing.

Treatment of HUF cells with BaP frequently induced mutations including $\mathrm{G}$ to $\mathrm{T}$ transversions (a landmark mutation of $\mathrm{BaP}$ exposure) on codons 157, 158, and 273 of the TP53 gene; these correspond to positions frequently mutated in human lung cancer [86, 87]. A potent mutagen present in diesel exhaust particles, 3nitrobenzanthrone, induces $\mathrm{G}$ to $\mathrm{T}$ transversions in HUF cells [88]. In HUF cells treated with aristolochic acid, an A to $\mathrm{T}$ transversion is induced in codon 139, which is registered as a frequently mutated site in the IARC p53 mutation database [89]. Taken together, these observations indicate that HUF cells are potentially useful for identifying mutagen-specific mutation sites on the TP53 gene, and thus can be used to reveal the mechanisms by which environmental mutagens cause carcinogenesis.

\section{TP53 gene mutation in lung cancer and molecular signature} induced by inhalation of environmental mutagens

Inhalation of mutagens is recognized to cause lung cancer, and air pollutants and tobacco smoke are suspected to be major causes of in vivo mutagenesis of protooncogenes and tumor suppressor genes in lung. Among proto-oncogenes and tumor-suppressor genes, TP53 is frequently mutated gene in lung cancer; about $40 \%$ of all lung cancer cases compiled in the IARC TP53 database [83] carry a mutated TP53 gene. A unique characteristic of TP53 mutation in lung cancer is a high rate of occurrence of $\mathrm{G}$ to $\mathrm{T}$ transversions; this rate is comparable to that of $\mathrm{G}$ to $\mathrm{A}$ transitions, which are common mutations in the TP53 gene in all types of cancer, including lung $[81,90]$. The frequently mutated codons (hotspots) on the TP53 gene in lung cancer are codons $157,158,175$, $245,248,249$, and 273 [91].

$\mathrm{G}$ to $\mathrm{T}$ transversion is a base substitution induced not only by administration of BaP via formation of BPDEDNA adducts [50,92] but also by generation of reactive oxygen species via formation of 8-oxo-deoxyguanine $[93,94]$. Because the lung is an organ directly in contact with air, it is reasonable to expect that $G$ to $T$ transversions that are induced by exogenous agents such as PAHs or oxygen would occur frequently in lung cancer. Mutation spectrum analysis has shown that the rate of $\mathrm{G}$ to $\mathrm{T}$ transversions in the lung cancer of smokers (about 30\%) is higher than that of nonsmokers $(10 \%-15 \%)[90,91,95]$. However, experimental inhalation of environmental tobacco smoke to Big Blue mice showed that the most common mutation induced on the $c I I$ gene was $\mathrm{G}$ to $\mathrm{A}$ transition and the next was $G$ to $T$ transversion [96].

I analyzed the IARC TP53 database to reveal the mutation spectrum at the level of nucleotide sequence of the TP53 gene in lung cancer, and potentially identify agent(s) contributing to mutagenesis of the TP53 gene. Table 1 summarizes my analysis of the base substitutions in frequently mutated codons in the TP53 gene in lung cancer [91]. It is well-known that mutations are mainly induced at CpG sites on the TP53 gene in human cancer [81]. As shown in Table 1, G to $\mathrm{T}$ transversions were induced in lung cancer on 5 guanine residues centered in CGN triplets at nucleotide \#12457 of codon 157 (CGT to CTT), \#12461 of codon 158 (CGC to CTC), \#13370 of codon 245 (CGG to CTG), \#13380 of codon 248 (CGG to CTG), and \#13799 of codon 273 (CGT to CTT). The triplets (CGC, CGT, and CGG), in which G to $\mathrm{T}$ transversions were induced in the TP53 gene, were identical to those containing the BaP-induced mutation hotspots (nucleotide numbers 125, 140, 143, and 413 on the gpt gene) in the lungs of gpt delta mice [50]. These observations confirm the speculation that $\mathrm{G}$ to $\mathrm{T}$ transversions on mutated TP53 genes in lung cancer may be induced by $\mathrm{BaP}$ and other carcinogenic PAHs contained in tobacco smoke [90, 91, 97].

$\mathrm{G}$ to $\mathrm{A}$ transitions were also frequently induced in lung cancer. $\mathrm{G}$ to $\mathrm{A}$ transitions were induced at 4 guanine residues, that is, at nucleotide \#12512 of codon 175 (CGC to CAC), \#13380 and \#13381 of codon 248 (CGG to CAG), and \#13799 of codon 273 (CGT to CAT). Among these triplets, guanine residues centered in CGT and CGG were also mutation hotspots for G to A transitions induced by inhalation of diesel exhaust in the lungs of gpt delta mice (nucleotide numbers 64, 110, and 115 of the gpt gene) [54]. Again, these findings indicate that air pollutants emitted from diesel engines and other fossil fuel combustion processes may contribute, at least partly, to mutagenesis of the TP53 gene, but the possibility that spontaneous mutations were enhanced on frequently mutated codons on TP53 gene cannot be ruled out, because $\mathrm{G}$ to A transitions occur frequently as spontaneous mutations. Nevertheless, it is clear that comparison between the mutation spectra of protooncogenes and tumor suppressor genes in lung cancers and those of in vivo mutations in transgenic rodent assays can provide clues to the identify of environmental mutagens that cause cancer.

\section{Correlation between in vivo mutagenicity and carcinogenicity}

As mentioned above, transgenic rodents are a good tool for evaluating the potential of environmental chemicals to induce mutations in vivo. However, more investigation is required to reveal the relationship between the potencies of in vivo mutagenicity and carcinogenicity. Suzuki [98] reported that $\mathrm{TD}_{50}$ (value of chronic doserate $[\mathrm{mg} / \mathrm{kg}$ body weight/day] that would induce tumors in half the test animals at the end of a standard lifespan 


\begin{tabular}{|c|c|c|c|c|c|c|c|c|}
\hline $\begin{array}{c}\text { Codon } \\
\text { number in } \\
\text { TP53 } \\
\text { gene }\end{array}$ & $\begin{array}{c}\text { Base } \\
\text { number in } \\
\text { TP53 } \\
\text { gene }\end{array}$ & $\begin{array}{c}\text { Number of } \\
\text { mutants in } \\
\text { the } \\
\text { database }\end{array}$ & $\begin{array}{l}\text { Number of } \\
\text { G to } A \\
\text { transitions } \\
\text { at non-CpG } \\
\text { sites }\end{array}$ & $\begin{array}{l}\text { Number of } \\
\text { G to A } \\
\text { transitions } \\
\text { at CpG } \\
\text { sites }\end{array}$ & $\begin{array}{c}\text { Number of } \\
\text { G to C } \\
\text { transversio } \\
\text { ns }\end{array}$ & $\begin{array}{c}\text { Number of } \\
\text { G to T } \\
\text { transversio } \\
\text { ns }\end{array}$ & $\begin{array}{c}\text { DNA sequence } \\
\text { change at major } \\
\text { mutation site }\end{array}$ & \\
\hline \multirow[t]{4}{*}{157} & & 83 & 2 & 3 & 1 & 67 & & \\
\hline & 12457 & 77 & & 3 & 1 & 67 & $\mathrm{CGT}>\mathrm{CTT}$ & \\
\hline & 12458 & 4 & & & & & & \\
\hline & 12459 & 2 & 2 & & & & & \\
\hline \multirow[t]{4}{*}{158} & & 89 & & 5 & 14 & 65 & & \\
\hline & 12460 & 11 & & 1 & 6 & & & \\
\hline & 12461 & 77 & & 4 & 8 & 65 & $\mathrm{CGC}>\mathrm{CTC}$ & \\
\hline & 12462 & 1 & & & & & & \\
\hline \multirow[t]{4}{*}{175} & & 68 & & 42 & 10 & 16 & & \\
\hline & 12511 & 18 & & 5 & 8 & 4 & & \\
\hline & 12512 & 49 & & 37 & 1 & 11 & $\mathrm{CGC}>\mathrm{CAC}$ & \\
\hline & 12513 & 1 & & & 1 & & & \\
\hline \multirow[t]{4}{*}{179} & & 59 & 15 & & 8 & 3 & & \\
\hline & 12523 & 27 & 15 & & 8 & 3 & & \\
\hline & 12524 & 29 & & & & & & \\
\hline & 12525 & 3 & & & & & & \\
\hline \multirow[t]{4}{*}{245} & & 98 & 10 & 10 & 9 & 62 & & \\
\hline & 13370 & 64 & & 10 & 7 & 41 & $\mathrm{CGG}>\mathrm{CTG}$ & \\
\hline & 13371 & 32 & 9 & & 2 & 20 & & \\
\hline & 13372 & 2 & 1 & & & 1 & & \\
\hline \multirow[t]{4}{*}{248} & & 153 & 1 & 83 & 6 & 59 & & \\
\hline & 13379 & 49 & & 46 & 2 & & $(\mathrm{CGG}>\mathrm{CAG})$ & \\
\hline & 13380 & 102 & & 37 & 3 & 59 & $C G G>C A G$ & $\mathrm{CGG}>\mathrm{CTG}$ \\
\hline & 13381 & 2 & 1 & & 1 & & & \\
\hline \multirow[t]{4}{*}{249} & & 124 & 2 & & 14 & 80 & & \\
\hline & 13382 & 25 & & & & & & \\
\hline & 13383 & 43 & 2 & & 2 & 36 & AGG $>$ ATG & \\
\hline & 13384 & 56 & & & 12 & 44 & $\mathrm{GGC}>\mathrm{GTC}$ & \\
\hline \multirow[t]{4}{*}{273} & & 159 & & 81 & 9 & 65 & & \\
\hline & 13797 & 37 & & 27 & 3 & 4 & & \\
\hline & 13798 & 121 & & 54 & 6 & 61 & CGT $>$ CAT & $\mathrm{CGT}>\mathrm{CTT}$ \\
\hline & 13799 & 1 & & & & & & \\
\hline \multicolumn{9}{|c|}{ Parentheses surround an antisense sequence } \\
\hline \multicolumn{9}{|c|}{ Green characters indicate $\mathrm{G}$ to $\mathrm{A}$ transitions. } \\
\hline Red char & cters indicat & G $\mathrm{G}$ to $\mathrm{T}$ tran & sversions. & & & & & \\
\hline
\end{tabular}

[99]) was associated with fold-increase in mutant frequency in transgenic rodents per total dose administered to the animals. Recently, Ono and Honma [100] presented the possibility that $\mathrm{BMDL}_{10}$ (the lower $95 \%$ confidence bound on the benchmark dose corresponding to $10 \%$ specific change) of carcinogenicity can be 
predicted from the $\mathrm{BMDL}_{10}$ of mutagenicity in the transgenic rodents. Therefore, it is important to precisely analyze the relationship between in vivo mutagenicity in the transgenic rodent assay and the carcinogenicity of various chemicals.

For this purpose, I extracted dose-response data for carcinogenicity from the Carcinogenic Potency Database (CPDB) [99], which contains the dose-response data for 1547 chemicals; and I obtained data on in vivo mutagenicity of 163 chemicals in transgenic rodent assays from the published literature [35]. At the Annual Meeting of Japanese Environmental Mutagen Society in 2009 [101], based on preliminary data, I put forward the hypothesis that $\mathrm{TD}_{50}$ values of genotoxic carcinogens correlate to the values of in vivo mutagenic potency if compared for the same target organ and administration route. Because the $\mathrm{TD}_{50}$ value in CPDB is the harmonic mean calculated from the $\mathrm{TD}_{50}$ value of the most potent target site, in the current study I obtained $\mathrm{TD}_{50}$ values of genotoxic carcinogens in liver and lung for each route of administration (inhalation, oral gavage or diet, or ip injection) by calculating harmonic means of the values cited in CPDB except benzene (see Additional file 1). I defined in vivo mutagenic potency as the harmonic mean of the total dose of agents administered to an animal (total dose) divided by the induced mutant frequency (the mutant frequency of the treatment group minus the mutant frequency of the control group) $\times 10^{5}$ (IMF); the values for total dose and IMF used for this calculation were extracted from reference [35].

The criteria of dose-response data used for calculation of $\mathrm{TD}_{50}$ in mouse liver and lung were as follows: 1 ) dose-response data with two or more doses were used, and if this was not available, one-dose data were used; 2) if more than one tumor type was induced in the organ, data from the various tumor types was combined for the calculation; 3) if dose-response data with two or more doses were used, the dose-response curve that was consistent with linearity (marked as '*' in CPDB) was used for the calculation; 4) the data in CPDB were evaluated as showing positive carcinogenicity (marked as c or + in the database); 5) the number of animals per group was over ten, 6) the incidence of tumors in the control and the elevation of incidence in treatment groups was below $40 \%$ and over $10 \%$, respectively; and 7) the significance of the correlation of dose-response was $P<0.10$. For calculating in vivo mutagenic potencies, total doses obtained by multiple-time dosing cited in reference [35] were used, except for total dose for inhalation, which was re-calculated as indicated in Additional file 1. The calculated values of the harmonic means of $\mathrm{TD}_{50}$ and total dose/IMF (T/I) of each chemical and the data for calculating these values are listed in Table 2 and Additional file 1, respectively.
Table 2 Harmonic means of $\mathrm{TD}_{50}$ values and total dose/IMF ( $\mathrm{T} /$ I; potency of in vivo mutagenicity) values of genotoxic carcinogens in mouse liver and lung

\begin{tabular}{|c|c|c|c|}
\hline Tissues & $\begin{array}{l}\text { Compounds } \\
\text { (administration method) }\end{array}$ & $\begin{array}{l}\text { Harmonic mean of } \\
\mathrm{TD}_{50}(\mathrm{mg} / \mathrm{kg} / \text { day) }\end{array}$ & $\begin{array}{l}\text { Harmonic mean } \\
\text { of } \mathrm{T} / \mathrm{l}(\mathrm{mg} / \mathrm{kg})\end{array}$ \\
\hline \multirow[t]{9}{*}{ Liver } & $\begin{array}{l}\text { 2-acetylaminofluorene } \\
\text { (diet) }\end{array}$ & 7.81 & 231 \\
\hline & 4-aminodiphenyl (diet) & 1.58 & 15.3 \\
\hline & $\begin{array}{l}\text { 4-chloro-o- } \\
\text { phenylenediamine (diet) }\end{array}$ & 1341 & 7623 \\
\hline & 2,4-diaminotoluene (diet) & 26.7 & 1688 \\
\hline & dichloroacetic acid (diet) & 155 & 66867 \\
\hline & MelQ (diet) & 27.1 & 272 \\
\hline & MelQx (diet) & 24.3 & 104 \\
\hline & $\begin{array}{l}N \text {-nitrosodimethylamine } \\
\text { (gavage) }\end{array}$ & 0.253 & 0.69 \\
\hline & urethane (diet) & 39 & 427 \\
\hline \multirow[t]{5}{*}{ Lung } & benzene (inhalation) & 175 & 4937 \\
\hline & 1,3-butadiene (inhalation) & 41.8 & 532 \\
\hline & $\begin{array}{l}\text { cyclophosphamide } \\
\text { (ip injection) }\end{array}$ & 5.92 & 16.6 \\
\hline & $\begin{array}{l}\text { ethylene oxide } \\
\text { (inhalation) }\end{array}$ & 63.4 & 897 \\
\hline & urethane (diet) & 28.3 & 303 \\
\hline
\end{tabular}

The data for calculating these values are listed in Additional file 1

I analyzed whether the harmonic mean values of $\mathrm{TD}_{50}$ of mouse liver or lung correlated to $\mathrm{T} / \mathrm{I}$ values (in vivo mutagenic potencies). As shown in Fig. 1, log [harmonic mean of $\mathrm{TD}_{50}$ ] (hereafter, $\log \mathrm{TD}_{50}$ ) was linearly related to $\log$ [harmonic mean of $\mathrm{T} / \mathrm{I}$ ] (hereafter, $\log \mathrm{T} / \mathrm{I})$, suggesting that carcinogenicity of genotoxic carcinogens could be predicted from the target and route-matched in vivo mutagenicity. This linear correlation between $\log \mathrm{TD}_{50}$ and $\log \mathrm{T} / \mathrm{I}$ was an unexpected finding, since the carcinogenicity of a genotoxic substance can be affected by the substance's tumor promoting activity. Among various in vitro assay systems for predicting carcinogenicity, the Bhas assay, which uses a clone of BALB/c 3 T3 cells transfected with the v-Ha-ras gene, is an established system for evaluating the tumor promoter activity. The tumor promoter activity of several substances listed in Table 2 have previously been tested by Bhas assay; 2,4-diaminotoluene and urethane (ethyl carbamate) were evaluated to be negative, but 2-acetylaminofluorene was positive [102], indicating that, even if a genotoxic carcinogen possesses tumor promoter activity, the plots of carcinogenicity $\left(\log \mathrm{TD}_{50}\right)$ vs. in vivo mutagenicity $(\log \mathrm{T} / \mathrm{I})$ show linearity. This observation suggests that the carcinogenicity of chemical substances that exert in vivo mutagenicity in the transgenic mouse system could be mainly driven by the mutagenicity (tumor initiator activity), at 


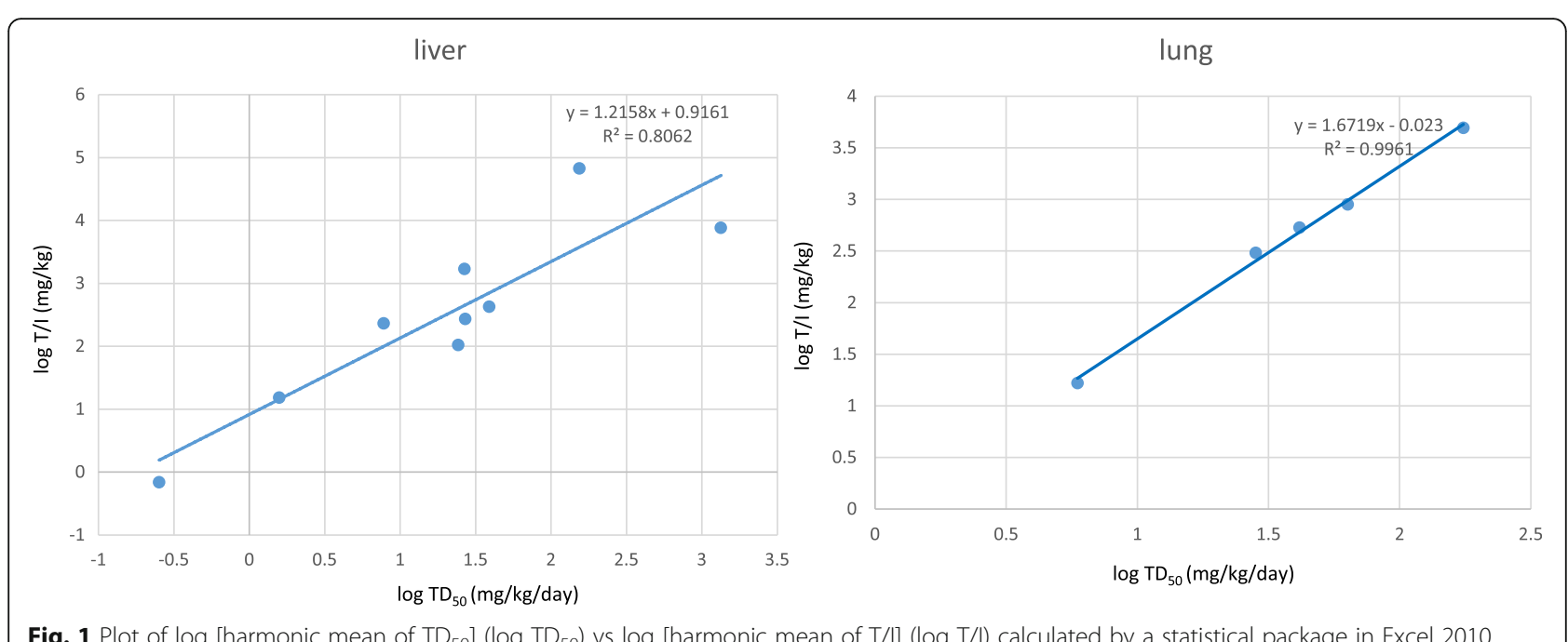

least, in liver. However, the mechanistic basis of this linear relationship remains to be further studied.

As a case study, the $\mathrm{TD}_{50}$ value of diesel exhaust was estimated from the harmonic mean of the T/I values (i.e., 105) in our study [58] (see Additional file 2). In a previous study, Ichinose et al. [103] demonstrated that the incidence of tumor in mouse lung was significantly elevated 3.1-fold by intratracheal administration of diesel exhaust particle at the dose of $0.1 \mathrm{mg} / \mathrm{animal}$, repeatedly 10 times at weekly intervals, comparing with the vehicle control. Using the formula of the relationship between the carcinogenic potency and in vivo mutagenicity (Fig. 1), I estimate the $\mathrm{TD}_{50}$ of diesel exhaust to be $17 \mathrm{mg} / \mathrm{kg} /$ day $(0.51 \mathrm{mg} /$ animal/day, if body weight is $0.03 \mathrm{~kg})$.

\section{Conclusions}

By using transgenic rodent assay systems, one can detect mutations induced on genomic DNA at the level of alterations in the nucleotide sequence. These assay systems are a good tool for evaluating in vivo mutagenicity induced by inhalation of air pollutants, especially a whole mixture of air pollutants. Merits of these assay systems are that they enable 1) analysis of the mutation spectrum (the types of mutation, e.g., transition, transversion, or deletion, and their positions on the genome), and 2) quantitative measurement of the potency of in vivo mutagenicity in somatic cells and germ cells.

I therefore propose that 1 ) comparisons between the nucleotide sequences of mutation hotspots induced in somatic cells by exposure to mutagens and the frequently mutated nucleotide sequences on proto-oncogenes and tumor suppressor genes may provide information about the identify of mutagen(s) causing cancer; and 2) a linear relationship exists between $\log \mathrm{TD}_{50}$ (carcinogenicity) and $\log \mathrm{T} / \mathrm{I}$ (in vivo mutagenicity), suggesting that carcinogenicity can be predicted from in vivo mutagenicity in the target organ of cancer. Data suggesting that air pollutants induce mutations on germ cells, as well as somatic cells, have been presented; however, further studies are required to assess the potency of mutation in germ cells from in vivo mutagenicity data. Recently, a high-throughput method for analyzing the mutation spectrum of target genes has been developed by using a next-generation sequencer $[104,105]$. Novel technologies will strength a potential of transgenic rodent assay systems for assessing the carcinogenic risk of environmental mutagens.

A part of this review was presented in a lecture of JEMS Award 2016 in the Annual Meeting of Japanese Environmental Mutagen Society in 2016.

\section{Additional files}

Additional file 1: The data for calculating $\mathrm{TD}_{50}$ and $\mathrm{T} / \mathrm{I}$. Parentheses: route of administration. Pathology: ade, adenoma; hpa, hepatoadenoma; hpc, hepatocarcinoma; hpt, hepatoma; mal, malignant tumor; mix, more than one tumor type; MXA, more than one tumor type, combined by National Cancer Institute/National Toxicology Program [99]. Transgenic Strain: BB, Big Blue mouse; Muta, Muta mouse; gpt, gpt delta mouse; Lac $Z$ plasmid, transgenic mouse harboring plasmids containing the lac $Z$ gene $[36,37]$.

\#TD ${ }_{50}$ for benzene calculated from the data [106] by the procedure of CPBD. $300 \mathrm{ppm} \times 1 / 3$ (1 week exposure followed by 2 weeks non-exposure) $=100 \mathrm{ppm}$. Incidence of lung adenoma in the exposed group and non-exposed group: $26 \%$ (15/54) and 7\% (3/46), respectively. Concentration of benzene corresponding to $50 \%$ increased incidence (incidence of lung adenoma, 54\%) $=250 \mathrm{ppm}$. $250 \mathrm{ppm} \times 78.11$ (molecular weight) $/ 24.45 \mathrm{~L}$ (standard volume) $=0.8 \mathrm{mg} / \mathrm{L}$. $0.8(\mathrm{mg} / \mathrm{L}) \times 0.03 \mathrm{~L} / \mathrm{min}$ (inhalation volume) $\times 60(\mathrm{~min}) \times 6 \mathrm{~h} /$ day (hours of inhalation per day $/ 0.03 \mathrm{~kg}$ (body weight) $=288 \mathrm{mg} / \mathrm{kg} / \mathrm{day}$. Duration of exposure: 81 weeks. Life time of mouse: 104 weeks. $\mathrm{TD}_{50}=288 \times(81 \text { weeks } / 104 \text { weeks })^{2}=175 \mathrm{mg} / \mathrm{kg} /$ day .

The total doses were re-calculated at the conditions in the references cited in [35].

*benzene. $300 \mathrm{ppm} \times 78.11$ (molecular weight)/24.45 (L, standard volume $)=0.96 \mathrm{mg} / \mathrm{L}$.

$0.96(\mathrm{mg} / \mathrm{L}) \times 0.03 \mathrm{~L} / \mathrm{min}$ (inhalation volume) $\times 60(\mathrm{~min}) \times 6 \mathrm{~h} /$ day

(hours of inhalation per day) $/ 0.03 \mathrm{~kg}$ (body weight) $\times 5$ days 
(inhalation days per a week) $\times 12$ weeks (duration of inhalation) $=$ $20,736 \mathrm{mg} / \mathrm{kg}$

**1,3-butadiene. $625 \mathrm{ppm} \times 54.09 / 24.45=1.38 \mathrm{mg} / \mathrm{L} .1 .38 \times 0.03 \times$ $60 \times 6 / 0.03 \times 5$ days (duration of inhalation) $=\mathbf{2 , 5 0 0} \mathbf{~ m g} / \mathbf{k g}$.

***ethylene oxide. $200 \mathrm{ppm} \times 44.05 / 24.45=0.36 \mathrm{mg} / \mathrm{L} .0 .36 \times 0.03 \times$ $60 \times 6 / 0.03 \times 5 \times 4=\mathbf{2 , 6 0 0 ~} \mathbf{m g} / \mathbf{k g}$. (XLSX $19 \mathrm{~kb})$

Additional file 2: Estimation of $\mathrm{T} / \mathrm{I}$ for diesel exhaust. T/I of diesel exhaust was estimated based on our data [53]. (DOCX $13 \mathrm{~kb}$ )

\section{Abbreviations}

1,3-BD: 1,3-butadiene; ACB-PCR: Allele-specific competitive blocker PCR; BaP: Benzo[a]pyrene; BPDE: Benzo[a]pyrene diol epoxide; CPDB: Carcinogenic potency database; ESTR: Expanded simple tandem repeat; HUF: Hupki mouse-derived embryonic fibroblast; Hupki: human p53 knock-in; IMF: Induced mutant frequency; ip: Intraperitoneal; PAH: polycyclic aromatic hydrocarbon; SPM: Suspended particulate matter; T/I: Total dose/IMF; $\mathrm{TD}_{50}$ : Value of chronic dose-rate $[\mathrm{mg} / \mathrm{kg}$ body weight/day] that would induce tumors in half the test animals at the end of a standard lifespan

\section{Competing interests}

The author declares that he has no competing interests.

\section{Received: 30 July 2016 Accepted: 6 December 2016}

\section{Published online: 01 April 2017}

\section{References}

1. [ http://www2.env.go.jp/chemi/prtr/prtrinfo/contents/e-outline.jsp ]. (April 28, 2016)

2. [http://www.env.go.jp/chemi/prtr/result/gaiyo.html]. (in Japanese, April 28, 2016).

3. [http://www.env.go.jp/air/osen/monitoring/mon_h25/index.html]. (in Japanese April 28, 2016).

4. Patel MM, Quinn JW, Jung KH, Hoepner L, Diaz D, Perzanowski M, Rundle A Kinney PL, Perera FP, Miller RL. Traffic density and stationary sources of air pollution associated with wheeze, asthma, and immunoglobulin E from birth to age 5 years among New York City children. Environ Res. 2011; 111(8):1222-9.

5. Tanaka M, Aoki Y, Takano H, Fujitani Y, Hirano S, Nakamura R, Sone Y, Kiyono $\mathrm{M}$, Ichinose $\mathrm{T}$, Itoh $\mathrm{T}$, et al. Effects of exposure to nanoparticle-rich or -depleted diesel exhaust on allergic pathophysiology in the murine lung. J Toxicol Sci. 2013;38(1):35-48.

6. Silva RA, Adelman Z, Fry MM, West JJ. The impact of individual anthropogenic emissions sectors on the global burden of human mortality due to ambient air pollution. Environ Health Perspect. 2016:124(11):1776-84.

7. Luch A. Nature and nurture - lessons from chemical carcinogenesis. Nat Rev Cancer. 2005;5(2):113-25.

8. IARC/WHO. Some Non-heterocyclic Polycyclic Aromatic Hydrocarbons and Some Related Exposures, IARC Monographs on the Evaluation of Carcinogenic Risks to Human vol. 92. Lyon; 2010.

9. IARC/WHO. Diesel and Gasoline Engine Exhausts and Some Nitroarenes, IARC Monographs on the Evaluation of Carcinogenic Risks to Human vol. 105. Lyon; 2014

10. Pope 3rd CA, Burnett RT, Thun MJ, Calle EE, Krewski D, Ito K, Thurston GD. Lung cancer, cardiopulmonary mortality, and long-term exposure to fine particulate air pollution. JAMA. 2002:287(9):1132-41.

11. Laden F, Schwartz J, Speizer FE, Dockery DW. Reduction in fine particulate air pollution and mortality: Extended follow-up of the Harvard Six Cities study. Am J Respir Crit Care Med. 2006;173(6):667-72.

12. Katanoda K, Sobue T, Satoh H, Tajima K, Suzuki T, Nakatsuka H, Takezaki T, Nakayama T, Nitta H, Tanabe K, et al. An association between long-term exposure to ambient air pollution and mortality from lung cancer and respiratory diseases in Japan. J Epidemiol. 2011;21(2):132-43.

13. IARC/WHO. Outdoor Air Pollution, IARC Monographs on the Evaluation of Carcinogenic Risks to Human vol. 109. Lyon; 2016.

14. Claxton LD, Matthews PP, Warren SH. The genotoxicity of ambient outdoor air, a review: Salmonella mutagenicity. Mutat Res. 2004:567(2-3):347-99.

15. Claxton LD, Woodall Jr GM. A review of the mutagenicity and rodent carcinogenicity of ambient air. Mutat Res. 2007:636(1-3):36-94.

16. Iwado H, Koyano M, Goto S, Kira S, Hayatsu H. Ubiquitous presence of mutagenic and antimutagenic components in air-borne particulates of two Japanese cities. Mutat Res. 1994;322(4):329-39.
17. Matsumoto M, Ando M, Tamura K. Difference of mutagenic activity of airborne particulates by particle size: Assay by the Salmonella microsuspension procedure. (in Japanese). Jpn J Toxicol Environ Health. 1993;39(2):139-47.

18. Watanabe T, Takahashi K, Konishi E, Hoshino Y, Hasei T, Asanoma M, Hirayama T, Wakabayashi K. Mutagenicity of surface soil from residential areas in Kyoto city, Japan, and identification of major mutagens. Mutat Res. 2008;649(1-2):201-12.

19. Wiencke JK. DNA adduct burden and tobacco carcinogenesis. Oncogene. 2002;21(48):7376-91.

20. Husgafvel-Pursiainen K. Genotoxicity of environmental tobacco smoke: a review. Mutat Res. 2004;567(2-3):427-45.

21. Vineis P, Husgafvel-Pursiainen K. Air pollution and cancer: biomarker studies in human populations. Carcinogenesis. 2005;26(11):1846-55.

22. Aoki Y, Hashimoto AH, Sato H, Matsumoto M. Potency of air pollutions at DNA adduct formation and assessment by in vivo mutagenesis. In: Alvarez E, Cunha R, editors. In DNA adducts: formation, detection and mutagenesis. Hauppange: Nova Science Publisher; 2010. p. 143-53.

23. Sato $H$, Suzuki KT, Sone $H$, Yamano $Y$, Kagawa J, Aoki Y. DNA-adduct formation in lungs, nasal mucosa, and livers of rats exposed to urban roadside air in Kawasaki City. Jpn Environ Res. 2003;93(1):36-44.

24. Soares SR, Bueno-Guimaraes HM, Ferreira CM, Rivero DH, De Castro I, Garcia $\mathrm{ML}$, Saldiva PH. Urban air pollution induces micronuclei in peripheral erythrocytes of mice in vivo. Environ Res. 2003;92(3):191-6.

25. Binkova B, Dobias L, Wolff T, Sram RJ. 32P-postlabeling analysis of DNA adducts in tissues of rats exposed to coke-oven emissions. Mutat Res. 1994;307(1):355-63.

26. Somers CM, Yauk CL, White PA, Parfett CL, Quinn JS. Air pollution induces heritable DNA mutations. Proc Natl Acad Sci U S A. 2002;99(25):15904-7.

27. Yauk $C L$, Quinn JS. Multilocus DNA fingerprinting reveals high rate of heritable genetic mutation in herring gulls nesting in an industrialized urban site. Proc Natl Acad Sci U S A. 1996;93(22):12137-41.

28. Yauk CL, Fox GA, McCarry BE, Quinn JS. Induced minisatellite germline mutations in herring gulls (Larus argentatus) living near steel mills. Mutat Res. 2000:452(2):211-8.

29. Somers CM, McCarry BE, Malek F, Quinn JS. Reduction of particulate air pollution lowers the risk of heritable mutations in mice. Science. 2004; 304(5673):1008-10.

30. Samet JM, DeMarini DM, Malling HV. Biomedicine. Do airborne particles induce heritable mutations? Science. 2004;304(5673):971-2.

31. Yauk C, Polyzos A, Rowan-Carroll A, Somers CM, Godschalk RW, Van Schooten FJ, Berndt ML, Pogribny IP, Koturbash I, Williams A, et al. Germline mutations, DNA damage, and global hypermethylation in mice exposed to particulate air pollution in an urban/industrial location. Proc Natl Acad Sci U S A. 2008;105(2):605-10.

32. Yauk CL, Berndt ML, Williams A, Rowan-Carroll A, Douglas GR, Stampfli MR Mainstream tobacco smoke causes paternal germ-line DNA mutation. Cancer Res. 2007:67(11):5103-6.

33. Marchetti F, Rowan-Carroll A, Williams A, Polyzos A, Berndt-Weis ML, Yauk CL. Sidestream tobacco smoke is a male germ cell mutagen. Proc Natl Acad Sci U S A. 2011;108(31):12811-4.

34. Somers CM. Expanded simple tandem repeat (ESTR) mutation induction in the male germline: lessons learned from lab mice. Mutat Res. 2006;598(1-2):35-49.

35. Lambert IB, Singer TM, Boucher SE, Douglas GR. Detailed review of transgenic rodent mutation assays. Mutat Res. 2005;590(1-3):1-280.

36. Martus HJ, Dolle ME, Gossen JA, Boerrigter ME, Vijg J. Use of transgenic mouse models for studying somatic mutations in aging. Mutat Res. 1995; 338(1-6):203-13.

37. Boerrigter ME, Dolle ME, Martus HJ, Gossen JA, Vijg J. Plasmid-based transgenic mouse model for studying in vivo mutations. Nature. 1995:377(6550):657-9.

38. Recio L, Osterman-Golkar S, Csanady GA, Turner MJ, Myhr B, Moss O, Bond JA. Determination of mutagenicity in tissues of transgenic mice following exposure to 1,3-butadiene and $\mathrm{N}$-ethyl-N-nitrosourea. Toxicol Appl Pharmacol. 1992;117(1):58-64.

39. Recio L, Meyer KG, Pluta $\sqcup$, Moss OR, Saranko CJ. Assessment of 1,3-butadiene mutagenicity in the bone marrow of B6C3F1 lacl transgenic mice (Big Blue): a review of mutational spectrum and lacl mutant frequency after a 5-day 625 ppm 1,3-butadiene exposure. Environ Mol Mutagen. 1996;28(4):424-9.

40. National Toxicology Program. Toxicological and carcinogenesis studies of 1,3-butadiene (CAS No. 106-99-0) in B6C3F1 mice (inhalation studies). Tech Rep Ser. No. 434. US Department of Health and Human Services; 1993.

41. Recio L, Meyer KG. Increased frequency of mutations at A:T base pairs in the bone marrow of $\mathrm{B} 6 \mathrm{C} 3 \mathrm{FF} 1$ lacl transgenic mice exposed to 1,3-butadiene. Environ Mol Mutagen. 1995;26(1):1-8. 
42. Recio L, Pluta LJ, Meyer KG. The in vivo mutagenicity and mutational spectrum at the lacl transgene recovered from the spleens of B6C3F1 lacl transgenic mice following a 4-week inhalation exposure to 1,3-butadiene. Mutat Res. 1998;401(1-2):99-110.

43. Recio L, Steen AM, Pluta LJ, Meyer KG, Saranko CJ. Mutational spectrum of 1,3-butadiene and metabolites 1,2-epoxybutene and 1,2,3,4diepoxybutane to assess mutagenic mechanisms. Chem Biol Interact. 2001;135-136:325-41.

44. Goggin M, Sangaraju D, Walker VE, Wickliffe J, Swenberg JA, Tretyakova N Persistence and repair of bifunctional DNA adducts in tissues of laboratory animals exposed to 1,3-butadiene by inhalation. Chem Res Toxicol. 2011; 24(6):809-17.

45. Sisk SC, Pluta LJ, Meyer KG, Wong BC, Recio L. Assessment of the in vivo mutagenicity of ethylene oxide in the tissues of B6C3F1 lacl transgenic mice following inhalation exposure. Mutat Res. 1997;391(3):153-64.

46. Recio L, Donner M, Abernethy D, Pluta L, Steen AM, Wong BA, James A, Preston RJ. In vivo mutagenicity and mutation spectrum in the bone marrow and testes of $\mathrm{B} 6 \mathrm{C} 3 \mathrm{~F} 1$ lacl transgenic mice following inhalation exposure to ethylene oxide. Mutagenesis. 2004;19(3):215-22.

47. Leavitt SA, George MH, Moore T, Ross JA. Mutations induced by benzo[a]pyrene and dibenzo[a, I]pyrene in lacl transgenic B6C3F1 mouse lung result from stable DNA adducts. Mutagenesis. 2008;23(6):445-50.

48. Long AS, Lemieux $C L$, Arlt VM, White PA. Tissue-specific in vivo genetic toxicity of nine polycyclic aromatic hydrocarbons assessed using the MutaMouse transgenic rodent assay. Toxicol Appl Pharmacol. 2016;290:31-42.

49. Hashimoto AH, Amanuma K, Hiyoshi K, Takano H, Masumura K, Nohmi T, Aoki $Y$. In vivo mutagenesis in the lungs of gpt-delta transgenic mice treated intratracheally with 1,6-dinitropyrene. Environ Mol Mutagen. 2006;47(4):277-83.

50. Hashimoto AH, Amanuma K, Hiyoshi K, Takano H, Masumura K, Nohmi T, Aoki Y. In vivo mutagenesis induced by benzo[a]pyrene instilled into the lung of gpt delta transgenic mice. Environ Mol Mutagen. 2005;45(4):365-73.

51. Sato H, Sone H, Sagai M, Suzuki KT, Aoki Y. Increase in mutation frequency in lung of Big Blue rat by exposure to diesel exhaust. Carcinogenesis. 2000; 21(4):653-61.

52. Dybdahl M, Risom L, Moller P, Autrup H, Wallin H, Vogel U, Bornholdt J, Daneshvar B, Dragsted LO, Weimann A, et al. DNA adduct formation and oxidative stress in colon and liver of Big Blue rats after dietary exposure to diesel particles. Carcinogenesis. 2003;24(11):1759-66.

53. Muller AK, Farombi EO, Moller P, Autrup HN, Vogel U, Wallin H, Dragsted LO, Loft S, Binderup ML. DNA damage in lung after oral exposure to diesel exhaust particles in Big Blue rats. Mutat Res. 2004;550(1-2):123-32.

54. Hashimoto AH, Amanuma K, Hiyoshi K, Sugawara Y, Goto S, Yanagisawa R, Takano H, Masumura K, Nohmi T, Aoki Y. Mutations in the lungs of gpt delta transgenic mice following inhalation of diesel exhaust. Environ Mol Mutagen. 2007;48(8):682-93.

55. Dybdahl M, Risom L, Bornholdt J, Autrup H, Loft S, Wallin H. Inflammatory and genotoxic effects of diesel particles in vitro and in vivo. Mutat Res. 2004:562(1-2):119-31.

56. McDonald JD, Doyle-Eisele M, Giglioyyi A, Miller RA, Seilkop S, Mauderly JL, Seagrave J, Chow J, Zielinska B. Part 1. Biologic responses in rats and mice tp subchronic inhalation of diesel exhaust from U.S. 2007-compliant engines: Report on 1-, 3-, and 12-month exposures in the ACES bioassay. Res Rep Health Eff Inst. 2012;166:9-120.

57. Bemis JC, Torous DK, Dertinger SD. Part 2. Assessment of genotoxicity after exposure to diesel exhaust from U.S. 2007-compliant diesel engines: report on 1- and 3-month exposures in the ACES bioassay. Res Rep Health Eff Inst. 2012;166:125-157

58. Hashimoto AH, Matsumoto M, Masumura K, Nohmi T, Aoki Y. In vivo mutagenesis caused by diesel exhaust in the testis of gpt delta transgenic mice. Gene Environ. 2009;31(1):1-9.

59. Aoki Y, Hashimoto AH, Amanuma K, Matsumoto M, Hiyoshi K, Takano H, Masumura K, Itoh K, Nohmi T, Yamamoto M. Enhanced spontaneous and benzo(a)pyrene-induced mutations in the lung of Nrf2-deficient gpt delta mice. Cancer Res. 2007;67(12):5643-8.

60. Masumura K, Matsui K, Yamada M, Horiguchi M, Ishida K, Watanabe M, Ueda $\mathrm{O}$, Suzuki H, Kanke $\mathrm{Y}$, Tindall KR, et al. Mutagenicity of 2-amino-1-methyl-6phenylimidazo $[4,5-b]$ pyridine $(\mathrm{PhIP})$ in the new gpt delta transgenic mouse. Cancer Lett. 1999;143(2):241-4.

61. Sram RJ, Binkova B, Rossner P, Rubes J, Topinka J, Dejmek J. Adverse reproductive outcomes from exposure to environmental mutagens. Mutat Res. 1999;428(1-2):203-15.
62. Liegibel UM, Schmezer P. Detection of the two germ cell mutagens ENU and iPMS using the LacZ/transgenic mouse mutation assay. Mutat Res. 1997;388(2-3):213-8

63. Masumura K, Toyoda-Hokaiwado N, Ukai A, Gondo Y, Honma M, Nohmi T. Estimation of the frequency of inherited germline mutations by whole exome sequencing in ethyl nitrosourea-treated and untreated gpt delta mice. Genes Environ. 2016;38:10.

64. Douglas GR, Gingerich JD, Soper LM, Jiao J. Toward an understanding of the use of transgenic mice for the detection of gene mutations in germ cells. Mutat Res. 1997;388(2-3):197-212.

65. Verhofstad N, van Oostrom CT, Zwart E, Maas LM, van Benthem J, van Schooten FJ, van Steeg H, Godschalk RW. Evaluation of benzo(a)pyrene-induced gene mutations in male germ cells. Toxicol Sci. 2011;119(1):218-23.

66. Olsen AK, Andreassen A, Singh R, Wiger R, Duale N, Farmer PB, Brunborg G. Environmental exposure of the mouse germ line: DNA adducts in spermatozoa and formation of de novo mutations during spermatogenesis. PLoS One. 2010;5(6):e11349.

67. O'Brien JM, Beal MA, Yauk CL, Marchetti F. Benzo(a)pyrene is mutagenic in mouse spermatogonial stem cells and dividing spermatogonia. Toxicol Sci. 2016

68. Xu G, McMahan CA, Walter CA. Early-life exposure to benzo[a]pyrene increases mutant frequency in spermatogenic cells in adulthood. PLoS One. 2014;9(1):e87439.

69. Polyzos A, Parfett C, Healy C, Douglas G, Yauk C. A single-molecule PCR approach to the measurement of induced expanded simple tandem repeat instability in vitro. Mutat Res. 2006;594(1-2):93-100.

70. Beal MA, Rowan-Carroll A, Campbell C, Williams A, Somers CM, Marchetti F, Yauk CL. Single-molecule PCR analysis of an unstable microsatellite for detecting mutations in sperm of mice exposed to chemical mutagens. Mutat Res. 2015;775:26-32.

71. Ritz C, Ruminski W, Hougaard KS, Wallin H, Vogel U, Yauk CL. Germline mutation rates in mice following in utero exposure to diesel exhaust particles by maternal inhalation. Mutat Res. 2011;712(1-2):55-8.

72. Barber RC, Hardwick RJ, Shanks ME, Glen CD, Mughal SK, Voutounou M, Dubrova YE. The effects of in utero irradiation on mutation induction and transgenerational instability in mice. Mutat Res. 2009;664(1-2):6-12.

73. Helleberg $H, X u H$, Ehrenberg L, Hemminki K, Rannug U, Tornqvist M. Studies of dose distribution, premutagenic events and mutation frequencies for benzo[a]pyrene aiming at low dose cancer risk estimation. Mutagenesis. 2001;16(4):333-7.

74. O'Brien JM, Walker M, Sivathayalan A, Douglas GR, Yauk CL, Marchetti F. Sublinear response in lacZ mutant frequency of Muta Mouse spermatogonial stem cells after low dose subchronic exposure to N-ethyl-Nnitrosourea. Environ Mol Mutagen. 2015;56(4):347-55.

75. Bos JL. ras oncogenes in human cancer: a review. Cancer Res. 1989; 49(17):4682-9.

76. Wiseman RW, Stowers SJ, Miller EC, Anderson MW, Miller JA. Activating mutations of the c-Ha-ras protooncogene in chemically induced hepatomas of the male B6C3 F1 mouse. Proc Natl Acad Sci U S A. 1986;83(16):5825-9.

77. Feng Z, Hu W, Chen JX, Pao A, Li H, Rom W, Hung MC, Tang MS. Preferential DNA damage and poor repair determine ras gene mutational hotspot in human cancer. J Natl Cancer Inst. 2002;94(20):1527-36.

78. McKinzie PB, Delongchamp RR, Chen T, Parsons BL. ACB-PCR measurement of K-ras codon 12 mutant fractions in livers of Big Blue rats treated with $\mathrm{N}$ hydroxy-2-acetylaminofluorene. Mutagenesis. 2006;21(6):391-7.

79. Wang Y, Meng F, Arlt VM, Mei N, Chen T, Parsons BL. Aristolochic acidinduced carcinogenesis examined by ACB-PCR quantification of H-Ras and K-Ras mutant fraction. Mutagenesis. 2011;26(5):619-28.

80. Parsons BL, Manjanatha MG, Myers MB, McKim KL, Shelton SD, Wang Y, Gollapudi BB, Moore NP, Haber LT, Moore MM. Temporal changes in K-ras mutant fraction in lung tissue of big blue $\mathrm{B} 6 \mathrm{C} 3 \mathrm{~F}(1)$ mice exposed to ethylene oxide. Toxicol Sci. 2013;136(1):26-38.

81. Soussi T, Beroud C. Significance of TP53 mutations in human cancer: a critical analysis of mutations at CpG dinucleotides. Hum Mutat. 2003;21(3):192-200.

82. Petitjean A, Mathe E, Kato S, Ishioka C, Tavtigian SV, Hainaut P, Olivier M. Impact of mutant p53 functional properties on TP53 mutation patterns and tumor phenotype: lessons from recent developments in the IARC TP53 database. Hum Mutat. 2007;28(6):622-9.

83. IARC TP53 database [http://p53.iarc.fr/] (April 28, 2016).

84. Denissenko MF, Pao A, Tang M, Pfeifer GP. Preferential formation of benzo[a]pyrene adducts at lung cancer mutational hotspots in P53. Science. 1996;274(5286):430-2. 
85. Besaratinia A, Pfeifer GP. Applications of the human p53 knock-in (Hupki) mouse model for human carcinogen testing. Faseb J. 2010;24(8):2612-9.

86. Liu Z, Muehlbauer KR, Schmeiser HH, Hergenhahn M, Belharazem D, Hollstein MC. p53 mutations in benzo(a)pyrene-exposed human p53 knockin murine fibroblasts correlate with p53 mutations in human lung tumors. Cancer Res. 2005;65(7):2583-7.

87. Reinbold M, Luo JL, Nedelko T, Jerchow B, Murphy ME, Whibley C, Wei Q, Hollstein M. Common tumour p53 mutations in immortalized cells from Hupki mice heterozygous at codon 72. Oncogene. 2008;27(19):2788-94.

88. vom Brocke J, Krais A, Whibley C, Hollstein MC, Schmeiser HH. The carcinogenic air pollutant 3-nitrobenzanthrone induces GC to TA transversion mutations in human p53 sequences. Mutagenesis. 2009;24(1):17-23.

89. Feldmeyer $\mathrm{N}$, Schmeiser $\mathrm{HH}$, Muehlbauer KR, Belharazem D, Knyazev $\mathrm{Y}$, Nedelko T, Hollstein M. Further studies with a cell immortalization assay to investigate the mutation signature of aristolochic acid in human p53 sequences. Mutat Res. 2006;608(2):163-8.

90. Hainaut $P$, Pfeifer GP. Patterns of p53 G-> T transversions in lung cancers reflect the primary mutagenic signature of DNA-damage by tobacco smoke. Carcinogenesis. 2001;22(3):367-74.

91. Toyooka S, Tsuda T, Gazdar AF. The TP53 gene, tobacco exposure, and lung cancer. Hum Mutat. 2003;21(3):229-39.

92. Besaratinia A, Pfeifer GP. Second-hand smoke and human lung cancer. Lancet Oncol. 2008;9(7):657-66.

93. Nakabeppu Y, Sakumi K, Sakamoto K, Tsuchimoto D, Tsuzuki T, Nakatsu Y. Mutagenesis and carcinogenesis caused by the oxidation of nucleic acids. Biol Chem. 2006;387(4):373-9.

94. Lee DH, Pfeifer GP. Translesion synthesis of 7,8-dihydro-8-oxo-2'-deoxyguanosine by DNA polymerase eta in vivo. Mutat Res. 2008;641(1-2):19-26.

95. Hainaut P, Olivier M, Pfeifer GP. TP53 mutation spectrum in lung cancers and mutagenic signature of components of tobacco smoke: lessons from the IARC TP53 mutation database. Mutagenesis. 2001;16(6):551-3. author reply $555-556$

96. Kim SI, Yoon Jl, Tommasi S, Besaratinia A. New experimental data linking secondhand smoke exposure to lung cancer in nonsmokers. FASEB J. 2012; 26(5):1845-54

97. Pfeifer $G P$, Hainaut $P$. On the origin of $G->T$ transversions in lung cancer. Mutat Res. 2003:526(1-2):39-43.

98. Suzuki T. Letters to Editor (in Japanese). Environ Mutagen Res. 2002;24:179-84.

99. Carcinogenic potency database [https://toxnet.nlm.nih.gov/cpdb/] (April 28, 2016).

100. [https://www.fsc.go.jp/fsciis/technicalResearch/show/cho99920141304] (in Japanese, April 28, 2016)

101. Aoki Y, Matsumoto M. Relationship between carcinogenic potency and in vivo mutagenicity of tested chemicals. In: Proceedings of 38th Annunal meeting of Japanese Environmental Society. Shizuoka;2009. p155.

102. Sakai A, Sasaki K, Muramatsu D, Arai S, Endou N, Kuroda S, Hayashi K, Lim YM, Yamazaki S, Umeda M, et al. A Bhas 42 cell transformation assay on 98 chemicals: the characteristics and performance for the prediction of chemical carcinogenicity. Mutat Res. 2010;702(1):100-22.

103. Ichinose T, Yamanushi T, Seto H, Sagai M. Oxygen radicals in lung carcinogenesis accompanying phagocytosis of diesel exhaust particles. Int J Oncol. 1997;11(3):571-5.

104. Besaratinia A, Li H, Yoon Jl, Zheng A, Gao H, Tommasi S. A high-throughput next-generation sequencing-based method for detecting the mutational fingerprint of carcinogens. Nucleic Acids Res. 2012;40(15):e116.

105. Beal MA, Gagne R, Williams A, Marchetti F, Yauk CL. Characterizing Benzo[a]pyrene-induced lacZ mutation spectrum in transgenic mice using next-generation sequencing. BMC Genomics. 2015;16(1):812.

106. Snyder CA, Sellakumar AR, James DJ, Albert RE. The carcinogenicity of discontinuous inhaled benzene exposures in CD-1 and C57BI/6 mice. Arch Toxicol. 1988:62(5):331-5

\section{Submit your next manuscript to BioMed Central and we will help you at every step:}

- We accept pre-submission inquiries

- Our selector tool helps you to find the most relevant journal

- We provide round the clock customer support

- Convenient online submission

- Thorough peer review

- Inclusion in PubMed and all major indexing services

- Maximum visibility for your research

Submit your manuscript at www.biomedcentral.com/submit
C Biomed Central 